\title{
Citizenship and Social Justice
}

\author{
Ton Bernts, ${ }^{1}$ Leo d'Anjou, ${ }^{1}$ and Dick Houtman ${ }^{1,2}$
}

\begin{abstract}
Discussions on the problems of the welfare state are increasingly framed in terms of citizenship rather than social justice. The popularity of the concept of citizenship raises the question of its implications for social justice theory and research. In this article it is argued that whereas the dominant approach in social justice is essentially individualistic, the concept of citizenship focuses rather on individuals as members of a societal community, from which both rights and obligations are derived. This focus on communal membership suggests three important topics for social justice theory and research: (i) the need to distinguish between a civic and a justice motive for human behavior, (ii) the need to specify the frame of reference respondents should use when they make their justice judgments, and (iii) the need to recognize the fact that justice judgments may result from both adhering to criteria of justice and considering the consequences of their application.
\end{abstract}

KEY WORDS: citizenship; social justice; welfare state; individual; community.

\section{INTRODUCTION}

Justice is commonly perceived as the central moral standard in social life. It constitutes, in the famous words of Rawls (1973), the first virtue of social institutions. Concepts of social justice are considered the guidelines of the way we order our world and perceive and evaluate social interaction. It is supposed, therefore, that "violation of our conceptions of justice presents a twofold threat: It challenges and weakens the moral base of our community and it brings into question the evaluative framework that pro-

${ }^{1}$ Social Faculty, Erasmus University, Rotterdam, The Netherlands.

${ }^{2}$ Address all correspondence to Dick Houtman, Social Faculty, L-04-34, Erasmus University, P.O. Box 1738, 3000 DR Rotterdam, The Netherlands. 
vides a foundation for our individual and social action" (Deutsch and Steil, 1988, p. 4).

Although justice forms the cornerstone of the social fabric, the concept used in social research to describe this phenomenon has principally an individualistic character. Justice is seen here as the fair balance of contributions and rewards of individuals. This individualistic explanation of social cooperation and social order (e.g., Hechter, 1987) has led to profound skepticism that goes back as far as Durkheim's (1893/1984) classical criticism on Spencer.

In the last decade the interest of social scientists in problems of distribution and hence of social justice has been growing. The welfare states have been censured severely, mainly for financial reasons. Scarcity has become a topic for social research, which resulted in the study of "questions of distributive justice, individual rights and notions of equality as the basis for social reconstruction and social reform" (Turner, 1990, p. 190). This renewed attention for questions of social justice has been increasingly framed in terms of the classic, but until recently almost outmoded, concept of citizenship. Central in this concept is the notion that citizens are not conceived as isolated individuals but as members of a community. They are individuals who have both rights that protect them from the harshness of (economic) life and obligations in order to preserve the social community.

There are indications that citizenship will become a new key concept of political discourse and social research. The growing popularity of the concept raises the question of the implications the concept of citizenship has for theory and research on social justice. To answer this question, we first give an account of the dominant approach in contemporary social justice theory and research. Then we elaborate on the concept of citizenship and the reasons for its revival. In the last section of this paper, we formulate some major implications the concept of citizenship holds for theory and research on social justice.

\section{DOMINANT APPROACH IN SOCLAL JUSTICE}

With his book Social Behavior, Homans (1961) set the tone for a distinct line of theory and research, viz., the study of social justice. He stated the general rule of distributive justice as follows: "A man in an exchange relation with another will expect that the rewards of each man be proportional to his costs- the greater the rewards, the greater the costs-and that the net rewards, or profits, of each man be proportional to his investments-the greater the investments, the greater the profit" (p. 75). Next Homans observed that individuals "do in fact perceive and appraise their 
rewards, costs, and investments in relation to the rewards, costs, and investments of other men" (p. 76). With this conceptualization Homans brought to the fore two notions in relation to justice: (i) the notion that individuals compare what they put into relations and get out of them with the inputs and outcomes of other individuals in similar situations, and (ii), the notion that the rewards of dealing with their fellow men have to be in proportion to what they put into those dealings-their investments and costs.

Homans' theorizing on social or distributive justice, with its base in Skinner's psychology and utilitarian economics, was readily picked up by (social) psychologists. This led to the formulation of equity theory which became the main paradigm in the study of social justice (Adams, 1963, 1965; Walster et al., 1973). In this theory Homans' notions of comparison and proportionality were thoroughly formalized into an equity formula which states that equity or justice is reached when the ratio of one's inputs and outcomes is equivalent to the input-outcome ratios of relevant others. Injustice exists when this balance is distorted. This leads to endeavors of unjustly treated individuals to restore-in one way or the other-the input-outcome balance.

With Homans and the equity theorists the study of social justice has gotten its distinctive characteristics. It focuses on the individual and on the way she/he compares, judges, and reacts to situations of (in)equity. Social justice is studied in experiments - the tradition of (social) psychology. Moreover, the emphasis lies more on the formal side of equity than on the substantive aspects of just situations and distributions, i.e., criteria of justice or fairness such as educational and occupational attainments or number of dependent children.

In their outstanding overview, Cohen and Greenberg (1982) show that there are other justice theories alongside equity theory. Leventhal, for instance, points to the importance of the criteria by which distributions of outcomes are defined and perceived as just. The "contributions rule"- the only rule equity theory recognizes-is not the only justice rule people employ. They often use rules like equality and need in allocating valued outcomes. Moreover, people may not always "try to maintain or restore actual outcomes to their deserved levels." There are-in Leventhal's view-situations in which people accept injustices (Leventhal, cited in: Cohen and Greenberg, 1982, pp. 21-22).

Lerner $(1975,1977)$ developed a justice theory that also differs from equity theory. He shows that (enlightened) self-interest--the keystone of every theory exclusively based on utilitarian notions-is not the only motive in human behavior. The insistence that people-alter as well as ego-should get what they deserve and what they are entitled to is important as well. Justice as equity is only one of the different forms of justice prevalent in 
human groups. Deutsch (1985) comes to the same conclusion. He sees equity theory as a limiting perspective, reflective of the dominant ideology in Western societies.

Leventhal, Lerner, and Deutsch, moreover, are more aware of the social character of beliefs, values, rules, and attitudes concerning social justice than the equity theorists. Still they maintain the emphasis on the individual and on experiments. This emphasis is also revealed in the overviews of Törnblom and Foa (1983) and of Cook and Hegtvedt (1983). The individualistic bias in social justice studies leads to marginal attention for the societal context. This conclusion holds, notwithstanding the important contribution of Berger et al. (1972). They showed that the "justice comparison" did not merely involve other individuals but rather generalized others embodied in referential structures which "contain information about rewards, or more exactly, goal-objects, typically associated with generalized objects."

This explicit acknowledgment of the social character of distribution rules had an important influence on the study of social justice. It led to studies in which distribution rules, beliefs about allocation, and referential standards are seen as socially determined. These rules or standards constitute the social context within which individuals act and react, i.e., allocate outcomes, judge those as fair, feel or perceive injustice, etc. (see e.g., Cook, 1975; Jasso and Rossi, 1977; Alves and Rossi, 1978; Cook and Yamagishi, 1983; Shepelak and Alwin, 1986; Alwin, 1987; Hermkens and Boerman, 1989; Griffith, 1990). In these studies, however, social justice is still largely a question of individuals comparing their situation (or those of others) with referential standards which is preferably researched in experiments or in factorial surveys. This emphasis on the individual can also be found in two papers directed at giving the sociological perspective its due in theory and research of social justice (Cook, 1987; Lerner, 1987).

As Rytina (1986) states, these studies (and the other foregoing social justice studies) form a distinct line of research in which the world outside the acting and evaluating individuals is taken as given. He shows that there is another tradition in the field of justice, viz., the study of collective responses to unjust social arrangements and of the way these arrangements are socially produced. This line of research remains, alas, according to Rytina distinct from the forementioned dominant research tradition.

It is, however, only fair to say that there are also developments towards a more sociological approach within the dominant-individualistic-tradition of justice research. First, Tallman and Ihinger-Tallman (1979) and Stolte (1987) put forward the importance of properties of the social structure, such as division of labor, formation of coalitions, and situations of power dependence, for the way justice norms and principles are formed and their content is determined. The notion of "relative deprivation" (Runciman, 
1966) points to another promising avenue for social justice research (Martin and Murray, 1983). Especially, the concept of fraternal deprivation-the situation of deprivation resulting from comparisons between groups and across structural dimensions, such as class, race, and gender-offers possibilities to widen the scope of social justice to issues of social stratification.

Second, in relation to this connection between social inequality and social justice Shepelak (1989) shows the important role of cultural factors, such as dominant ideologies (Kluegel and Smith, 1986), principles and norms of distributive justice (Hochschild, 1981), or myths, beliefs, or rationales (Robinson and Bell, 1978), in justifying (in)equality. Preferences for and judgments of allocations are shaped, according to Shepelak, by beliefs about fair shares, meritocracy, and opportunities, which are strongly tied to background variables and social position.

Third, there are attempts to develop individual-level theories of social justice into justice theories on the aggregate level (Jasso, 1978, 1980, 1989; Markovsky, 1985; Gartrell, 1985). Especially, Jasso's notion that the evaluation of justice by individuals forms the primordial independent variable that determines social phenomena, such as the propensity to dissolve, the degree of concord or discord, and the rate of conflict in a society, is important in assessing the role social (in)justice plays in the functioning of society. As Cohen and Greenberg (1982), state "the social collectivity [is] characterized by the distribution of 'justice' sentiments characteristic of its members ... [which] distribution ... [is] hypothesized to vary with important features of social aggregates" (pp. 25-26).

The foregoing overview shows that there is a wide diversity in the field of the study of social justice regarding the research questions and variables that are taken into account. There is in these studies, however, a common kernel which has not changed very much since Homans' pioneering work. Social justice still mainly refers to the comparisons individuals make between their situations and those of (generalized) others. Actions are seen as guided by the motive to attain or restore a fair balance between inputs and outcomes. This "justice motive" is conceived as the cornerstone of the social fabric, a perspective that implicitly assumes society to consist of a compilation of exchange relationships between otherwise isolated individuals.

\section{THE REEMERGENCE OF THE CONCEPT OF CITIZENSHIP}

As stated in the Introduction, recent discussions on the problems and the future of the welfare states are dominated by the concept of citizenship. 
In this section, we elaborate this concept further, thereby indicating the differences with the concept of social justice.

Citizenship is a product of the long-term process of modernization and denotes the equality of the members of the modern nation-state as a "societal community." This membership is protected against nonmembers, who can only attain the status of citizen when they meet specific conditions. Although the attempts of foreigners, immigrants, and refugees to attain membership of rich countries are a growing and important problem, we do not discuss this matter here (see in this respect e.g., Walzer, 1983), but we concentrate on the relevant aspects of the status people possess once citizenship is obtained.

Three different types of rights define citizenship as an equal status for all and constitute the basis for full membership in modern society (Marshall, 1965). The first type, the civil rights, was established in the 18th century. These rights refer to the guarantee of individual liberty and equality before the law. Next, there are the political rights, i.e., the right to vote and the right to stand for election. These rights were established in the 19th century. Social rights - established in the 20 th century-constitute the third type. They entitle people to "the whole range from the right to a modicum of economic welfare and security to the right to share to the full in the social heritage and to live the life of a civilized being according to the standards prevailing in the society" (Marshall, p. 78).

Civil and political rights can be equally achieved for all members of society, irrespective of their individual conditions. They are truly universal, since they require no more than the establishment of certain legal and political institutions. With respect to social rights, the situation is different. Social rights aim at enabling the participation of all members in a national community through a government-guaranteed delivery of services and provisions. Access to these services and provisions is restricted to those citizens whose circumstances prevent them from full participation in the national community.

As legal "claim rights" to government-guaranteed minimum standards of income, nutrition, health, housing and education, social rights constitute the heart of the welfare state (Wilensky, 1975, p. 1). They suppose an active state, which distributes services and provisions to citizens in certain conditions. This is a second important difference with civil and political rights, which do not require extensive state action. A third difference is the necessary lack of determinacy of social rights, compared to civil and political rights. They are always subject to change or further elaboration (Berting, 1990 , p. 190; Mishra, 1977, pp. 31-32). This indeterminacy is caused by the fact that needs are socially constructed by a community that collectively defines which circumstances are unacceptable and should thus be compen- 
sated for. Of course these definitions change over time, e.g., as a consequence of changes in the capacity of the fiscal basis of the state. Therefore, Walzer (1983, pp. 64-65) is right in emphasizing the particularistic character of social rights.

Social rights are thus guaranteed and implemented by an active state, which allocates services and provisions, thereby compensating as much as possible for individual circumstances. This prevents citizens to lead a life that is collectively defined as not acceptable.

In recent discussions about social rights in the Western welfare states the idea of citizenship is often-sometimes implicitly-used as a point of departure. The central question is whether the currently existing social rights do indeed result in full membership of society for all citizens. This question forms the background for the reemergence of the concept of citizenship. Some authors (Schuyt, 1983; Mead, 1986) argue that the existence of social rights weakens the awareness of one's social responsibilities which has negative consequences for the functioning of the community. We name this position communitarian. Others, e.g., Dahrendorf (1988) and Offe (1991), argue that the existing social rights are insufficient to ensure social participation to all. We name this second position left-libertarian.

The communitarian approach implies a particularistic point of view. Both social rights and social obligations flow, according to this view, from the specific traditions of a particular community. A formal and universal analysis of social justice in isolation from its wider social context is seen as invalid. Rather, the attention is focused on the way in which problems of social justice are connected with this context (Walzer, 1983; MacIntyre, 1988). This perspective suggests that attempts to attain a just distribution should not be studied in isolation from their wider social consequences, such as the fact that the guarantee of social rights might easily result in a neglect of civic responsibilities.

In a Dutch study on the feelings of people who receive social security, Schuyt (1983) found an interesting incongruence between attempts to distribute provisions justly and the feelings of justice of those involved. This phenomenon was, according to the author, caused by the fact that the striving for a just allocation of provisions required ever more refined rules and allocations to increasingly specific categories of citizens. As a consequence, it became difficult for people to understand why one person was entitled to a specific provision and another person was not. This resulted in feelings of injustice.

We see ourselves confronted with the paradox that the quest for justice may cause feelings of injustice and relative deprivation. These feelings may even stimulate additional claims leading to a situation wherein citizens take a "calculating" stand vis-à-vis a distributing state. Such processes imply 
an undermining of the awareness of civic responsibilities, which are both necessary for and presupposed by a smoothly functioning welfare state.

Mead (1986) takes a slightly different position and argues that the problem of the welfare state is not its size but its permissiveness. Traditional social policies, he states, have tended to ignore the behavioral problems of the poor. By demanding nothing in return for benefits, these policies undermine the capacity of those involved to function properly, resulting in a lack of social integration in mainstream society. Therefore, he argues, it is necessary to change existing social policies in such a way as to require the poor to meet certain standards of social functioning in exchange for the support given. More attention should thus be given to the social obligations attached to citizenship, especially work and education: "the federal programs that support the disadvantaged and unemployed have been permissive in character, not authoritative. That is, they have given benefits to their recipients but have set few requirements for how they ought to function in return ... There is good reason to think that recipients subject to such requirements would function better" (Mead, 1986, p. 1).

Both Schuyt and Mead argue that the provision of social rights can undercut people's sense of responsibility. This claim reveals that the strengthening of the community rather than the extension of social rights is seen as the ultimate political aim. From this communitarian perspective the sanctioning of those who fail to fulfill their social obligations is not legitimated by a principle of "equity." Rather, it is seen as a necessary correction of unacceptable behavior for the sake of the individual and the community. Bernts' (1988) study about opinions with respect to the distribution of health care indicates that such a communitarian motive for sanctioning exists.

The left-libertarian position with respect to social rights in the welfare state refers to social integration and citizenship as well. In this case, the individual citizen with his need for liberty and social participation is the point of departure. Authors like Dahrendorf (1988) and Offe (1991) stress the fact that the existing social rights do not lead to full membership of society for all: "Persistent poverty and long-term unemployment are new issues of citizenship, and the old instruments of the social state do not seem able to cope" (Dahrendorf, 1988, p. 45). Poverty and unemployment have led to an "underclass" in Western countries (Wilson, 1987; Engbersen, 1990), which is largely cut off from mainstream society. This raises important questions concerning the content of citizenship.

An important part of the problem is the fact that a reasonably paid job means far more than a way to make one's living. In modern Western society it is the dominant mode of social integration and social participation 
and therefore also an important precondition for full membership of the national community. For this reason, unemployment can only partially be compensated for by government programs that secure a minimum income to those who are out of work. Though both Dahrendorf and Offe value the progressive weakening of the linkage between market position and life chances as a consequence of the extension of social rights, they claim that this development has not kept certain categories of citizens from marginality and social isolation.

The establishment of a government-guaranteed right to work, however, is very difficult, at least when we reject the possibility that the state hires all unemployed, which recently is proposed under the name of "workfare." The difficulty results mainly from the fact that "no judge can force employers to hire unemployed people" (Dahrendorf, p. 148). Downward flexibility of real wages which is conforming to the requirements of the market provides an alternative option for attaining full employment. However, this strategy easily results in large-scale poverty, as experiences in the United States show: "Persistent poverty is the American equivalent to persistent unemployment in Europe" (p. 149). Since work remains a significant key to income and to full membership of society, Dahrendorf argues for the need to redistribute work, thus enabling those who currently remain in the margin, to participate fully in social life.

The relevance attached to individual liberty and individual needs, which made us label this position "left-libertarian," leads both Dahrendorf and Offe to argue for the establishment of a basic income, i.e., a right to income for all citizens independent of their inclination to accept paid employment. Especially Offe (1991) elaborated this proposal, which is not based upon employees' rights and duties, but upon citizens' rights and duties. Offe, like Dahrendorf, does accept forms of community service as a social obligation, as long as these are effectuated in the public domain.

The left-libertarian position focuses on the need for social participation and liberty of the individual citizen, whereas the communitarian position gives most attention to the community as a political ideal. However, we should not fail to see an important similarity, viz., the assumption that individuals together (should) constitute a community, the membership of which gives rise to both social rights and social obligations. According to both positions, modern society cannot and should not be conceived as merely an aggregation of exchange relationships between isolated individuals. Both are trying to "bring society back in," in contrast to Homans' (1964) ambition of "bringing men back in."

This means that a "civic motive" is seen as important alongside the "justice motive." The civic motive can be defined as an awareness of the fact that all citizens are part of a national community, from which both 
their own and other's social rights and social obligations are derived. The existence of this civic motive has, as we demonstrate in the next section, several important implications for theory and research on social justice.

\section{IMPLICATIONS FOR THEORY AND RESEARCH ON SOCLAL JUSTICE}

In the first section of this paper we analyzed the object of the contemporary, dominant approach in social justice theory and research. This object consists of the evaluations individuals make of the balance between their inputs and outcomes in the process of social interaction. Standards and criteria which constitute the basis for these evaluations are derived from a comparison of oneself with relevant others. The weight of these standards and criteria or the choice of the specific group of reference may vary according to the agreed upon definition of the situation. Workers, for instance, when judging the fairness of their income, have the choice to compare themselves with colleagues in the same factory, with other workers in the same factory who perform different tasks, or with people having different jobs in different factories. In all three instances a particular social context is defined as the source of the relevant criteria and, at the same time, as the range of their validity. But regardless of the agreed upon definition of the situation, it is always the individual who ultimately constitutes the norm on which the justice evaluation is based. Therefore, by taking justice as the only motive for social interaction, society is implicitly seen as, in the last resort, consisting of a compilation of exchange relationships of otherwise isolated individuals.

As we described in the second section, the concept of citizenship explicitly points out that society, on the contrary, should not be regarded as built exclusively on exchange relationships of individuals. This claim has taken on different forms. We have described the distinction between a communitarian and a left-libertarian interpretation of citizenship. The communitarian approach focuses especially on the condition and the continuation of the social community. The other version of citizenship aims at the individual by means of stressing his status as a citizen who deserves more than just his fair share of economic and social rights, viz., genuine participation in the social community.

Although differing at some points, both interpretations of citizenship should be seen as two sides of the same coin. Both stress the bond between individual and community. Etzioni (1988) speaks of an "I \& We concept" that "keeps challenging both individuals and the community to redefine the bond so as to reduce the strain, even if it cannot be eliminated. This 
is attempted, on the one side, by rendering the community to be more responsive to human nature ..., on the other, by improving the ability of individuals to function as members of a community ... and by enhancing civic obligations" (p. 82). Here, we see a reformulation of the forementioned communitarian and left-libertarian enterprises.

In this section, we elaborate on this rather abstract discussion and point out some concrete implications for theory and research on social justice. Our first remark pertains to the existence of so-called prosocial behavior that can only be explained by going beyond the justice motive and using the civic motive. This implies that social justice theory and research have to explore the lines that demarcate the situations in which the justice motive is predominant from those in which another motive prevails.

Our next remark relates to the validity of the results from studies of everyday judgments of justice or fairness. The existence of an encompassing community of citizens means that, to a degree yet to be explored, justice judgments are necessarily the result of different motives, i.e., of the justice and the civic motive. This problem may be solved - as we argue - by methodological provisions, viz., an explicit specification of the conditions under which the judgments are given.

Our third and last remark deals with the fact that the striving for justice has consequences for the social relationship of those concerned. These consequences can be seen as external effects that sometimes influence the justice judgments people give. This prevents an easy interpretation of these judgments in terms of the priority given to criteria or reference groups. The implication for social justice theory and research is the need to use a more qualitative approach.

\title{
Beyond the Justice Motive
}

\begin{abstract}
It is impossible for men to live together and be in regular contact with one another without their acquiring some feeling for the group which they constitute through having united together, without their becoming attached to it, concerning themselves with its interest and taking it into account in their behavior. And this attachment to something that transcends the individual, this subordination of the particular to the general interest, is the very well-spring of all moral activity. (Durkheim, 1893/1984, p. xliii)
\end{abstract}

This transcending of individual interests, as Durkheim calls it, constitutes a guideline of action which corresponds with what we have called a civic motive. Several studies demonstrate empirical evidence for the existence of this civic motive. A classic example is the study of Titmuss (1970), who made an analysis of reasons people gave for donating blood. He found a substantial group of people acting on the basis of civic or altruistic mo- 
tives: People gave blood without expecting any sort of service in return. According to Titmuss, the existence of a motive not based on reciprocity like the justice motive is especially important for modern welfare states where justice is to a large extent institutionalized. It should be avoided to rely exclusively on the market in order to create a fair balance between contribution and rewards, because, as Titmuss states, "the commercialization of blood and donor relationships represses the expression of altruism, erodes the sense of community" (p. 245). So, though a regulation through the market, or, for that matter, through taxation might result in a fair distribution of blood, going beyond a system of formalized exchange and distribution enhances communal spirit. This spirit is necessary for the creating of an encompassing solidaristic community and thus for the establishment of a firm basis of mutual trust which supports relationships guided by the justice motive.

Another important study in this respect is that of Bellah et al. (1985). Unlike Titmuss, the authors did not find many examples of prosocial behavior guided by altruistic or civic motives, but rather that their respondents regretted that these motives played but a subordinate role in their lives. Instead it appeared that the justice motive as a striving for fairness, for give-and-take, was widespread. Moreover, this motive was considered an ultimate form of individual self-reliance that "turns out to leave out very little place for interdependence and to correspond to a fairly grim view of the individual's place in the social world" (p. 15). Bellah et al. conclude that American citizens nowadays have lost the vocabulary of commitment, both in private and public affairs. The person who thinks in terms of the common good is, as the authors cite, a "sucker," because each individual is pursuing his or her own interests: "In this moral vacuum, it has been tempting to translate group claims and interests into the language of individual rights, a language that makes sense in terms of our dominant individualistic ideology" (p. 207). When we evaluate the findings of this study in the light of our argument we see ourselves confronted with the fact that underneath the apparent predominance of the justice motive, people look for other motives. Apparently, justice is not felt to be a sufficient guideline to live by. Therefore, the current reemergence of the concept of citizenship should not surprise us.

In accordance with the outcomes of these two studies, social justice theory and research should be aware of the limitations of the justice concept. Naturally, there is a whole range of social situations wherein the justice motive is the leading principle of action. Conflicts can arise out of differing evaluations of criteria and reference groups. However, in some occasions, the awareness of the community is predominant and people subordinate or postpone their justice claims. This calls for further study of the 
lines of demarcation between situations guided by the justice motive and those guided by the civic motive. The important differences and tensions between these two motives for social action can only be brought to light in this way.

Some remarks must be made in order to understand this paragraph properly. First, we used altruistic and civic motives more or less as synonyms. In fact, it is better to see the civic motive as a specific form of altruism on behalf of fellow citizens (and not close relatives or friends, etc.) and of the community as a whole (and not the family, etc.). Second, there has been an extensive dispute on the question whether altruistic-and for this reason civic-motives are ultimately guided by self-interest (see, for instance, Hechter, 1987) or not (see, for instance, Wolfe, 1989). We do not go into this discussion, but we confine ourselves to the remark that the results of the two forementioned studies cannot be explained without making a distinction between altruistic or civic motives on the one hand and justice motives on the other.

\section{Validity of Justice Judgments}

In the previous paragraph we stated that, in some instances, prosocial thoughts and behaviors can only be meaningfully explained by reference to a civic motive. This motive implies a limitation of the range of social situations in which the justice motive is predominant. In addition, the existence of a civic motive also questions the validity of the results from studies of judgments of justice or fairness. The reason is that respondents, when asked to give a justice judgment, may at the same time be conscious of their own and other people's status as citizen, which-as we have seen-entitles them to a certain level of provisions. This awareness complicates the interpretation of the results of justice studies, as is demonstrated in the following example.

In several Dutch studies on the justice of income (Hermkens, 1983; Berting, 1991; Steijn and De Witte, 1991) evidence is found supporting the proposition that merit criteria are heavily preferred to those of need. These outcomes may be explained by the fact that the respondents strongly favor an achieving society. On the other hand, we should keep in mind that the respondents also know-and probably justify-that welfare state institutions are backing up the needy, at least to a certain degree. Therefore, they may find need criteria, such as the number of dependents in a household, irrelevant for the working environment, because using these criteria would prevent a proper evaluation of work efforts and company results. If this line of thinking is correct, then the forementioned results have to be in- 
terpreted in a totally different way. Instead of concluding that the respondents hold the opinion that incomes should be distributed according to merit, we must take the possibility into account that the respondents think that need is an important criterion for income too, but that this is not the responsibility of the firm.

This means that, in order to assess the validity of a justice judgment, respondents have to be told explicitly which frame of reference they should use. This creates a transparent social situation in which the evaluation of the balance between inputs and outcomes can be optimally made. If we follow our example, this methodological requirement confines the question of just incomes to the workplace and enables us to draw conclusions with regard to the order of the preferred criteria for the allocation of income. We have to keep in mind that these justice judgments are only valid under restricted conditions.

The need to specify these conditions explicitly accounts for the popularity of the experimental method in studying social justice. When the subjects enter the abstract world of the experimental situation-of which they are aware - their only guideline for action and judgment is the fair balance of inputs and outcomes. Thus, the requirement for specified conditions is easily met. The creation of an abstract world, however, limits the validity of these experimental results. In everyday life justice judgments mix up with judgments arising from a civic motive to a degree we have to explore further. This brings us to our final remark.

\section{Justice and Its Consequences}

We have argued that justice judgments are valid under restricted conditions where isolated individuals are negotiating their respective inputoutcome balances. This raises a new question: How do people react when confronted with the necessity of making these restrictions? Under experimental conditions, this will probably not be an obstacle as the experimental situation is a specific excision of the social world, governed by a limited set of explicit rules. This means that an experiment is a game in which the decisions and judgments made have no consequences that reach further than the doors of the laboratory. The question is whether this is the same in normal, everyday life.

The concept of citizenship shows the awareness of the consequences that the adherence and appliance of justice rules have for the community. An example may clarify this point. In a study on risky life-styles as criteria for the distribution of health care (Bernts, 1988), it appeared that an equity-based treatment of risky behavior was rejected by several respondents, 
because of the expected consequences of assessing these risky behaviors. These respondents apparently feared the loss of their privacy and autonomy; a fear that influenced their justice judgments. This result shows that people are aware of the fact that justice judgments require an intersubjective assessment of inputs and outcomes, i.e., highly formalized social relationships.

A quite similar example can be taken from the work of Gilligan (1982) on gender-specific judgments of justice. In a critical analysis of Kohlberg's (1981) research on moral development, Gilligan discussed the apparent result that men attained a higher level of moral judgment. She rejected this interpretation and stated instead that women are more than men inclined to incorporate the effects of the justice rule that is applied in their justice judgments. Therefore they arrive at other judgments. Gilligan concluded that a female ethic of care should be distinguished from a male ethic of justice. In an ethic of care the appliance of justice rules is postponed or even abandoned in view of the consequences for the social situation.

In analogy with Gilligan's line of argument, people may postpone or abandon justice judgments in order not to endanger the community of individuals. When we consider our previous example of the judgments on income distribution for a moment, it is possible that some respondents do not apply merit criteria, not because they find them unimportant, but because they fear external effects of this strategy of rewarding, e.g., enhancing distrust or calculating behavior. In our opinion, the implication of the foregoing argument is that the study of social justice should be based more extensively on qualitative methods. Detailed reports of arguments on matters of justice can give us insight in the way people balance justice and civic motives. Consequentialist arguments and the vocabulary of citizenship in general can thus be brought to light.

\section{CONCLUSION}

We have shown that the concept of citizenship sharpens our understanding of the range and limits of the object of social justice theory and research. We have pointed out that the justice motive constitutes a guideline for action that in some respects is at odds with the notion of citizenship which requires that people consider each other as citizens with entitlements. Moreover, the limited range of the justice approach enhances the utility and validity of the very concept. Social justice offers only a clear guideline for individuals in specific situations, e.g., in economic transactions 
or in administrative procedures. This guideline is used alongside other values and motives like, as is described here at length, that of citizenship.

The complex interplay of these motives in everyday situations confronts theory and research on social justice with a difficult but challenging problem to unravel. We have made some proposals to start with. First, the lines of demarcation between situations guided by the justice motive and by the civic motive need to be studied more closely. Second, researchers have to specify the conditions on which the respondents should base their judgment explicitly. And last, the complex interplay of justice and civic motives in everyday situations may be studied better by a more qualitative approach.

\section{REFERENCES}

Adams, J. S. (1963). Toward an understanding of inequity. J. Abn. Soc. Psychol. 67: 422-436. Adams, J. S. (1965). Inequity in social exchange. In Berkowitz, L. (ed.), Advances in Experimental Social Psychology, Vol. 2, Academic Press, New York, pp. 267-299.

Alves, W., and Rossi, P. (1978). Who should get what? Fairness judgments of the distribution of earnings. Am. J. Sociol. 84: 541-564.

Alwin, D. F. (1987). Distributive justice and satisfaction with material well-being. Am. Sociol. Rev. 52: 83-95.

Bellah, R., Madsen, R., Sullivan, W. M., Swiddler, A., and Tipton, S. M. (1985). Habits of the Heart: Individualism and Commitment in American Life, Harper \& Row, New York.

Berger, J. Zelditch, M. Jr., Anderson, B., and Cohen, B. P. (1972). Structural aspects of distributive justice: A status value formulation. In Berger, J., Zelditch, M. Jr., Anderson, B. (eds.), Sociological Theories in Progress, Vol. 2, Houghton-Mifflin, Boston, pp. 119-146.

Bernts, T. (1988). Sanctioning risky life-styles? Soc. Justice Res. 2: 249-262.

Berting, J. (1990). Societal change, human rights and the welfare state in Europe. In Berting, J., et al. (eds.), Human Rights in a Pluralist World: Individuals and Collectivities, Meckler, London.

Berting, J. (1991). Nederlanders over de betekenis van individuele arbeidsprestaties [The Dutch about the meaning of individual work-related achievements]. In d'Anjou, L., and Bernts, T. (eds.), Presteren en Verdelen in Nederland: Over Individuele Belangen en Maatschappelijke Solidariteit [Achieving and Distributing in the Netherlands: On Individual Interests and Social Solidarity], Boom, Meppel/Amsterdam, The Netherlands, pp. 129150.

Cohen, R. L., and Greenberg, J. (1982). The justice concept in social psychology. In Greenberg, J., and Cohen, R. L. (eds.), Equity and Justice in Social Behavior, Academic Press, New York, pp. 1-41.

Cook, K. S. (1975). Expectations, evaluations, and equity. Am. Sociol. Rev. 40: 372-388.

Cook, K. S. (1987). Toward a more interdisciplinary research agenda: The potential contributions of sociology. Soc. Justice Res. 1: 5-18.

Cook, K. S., and Hegtved, K. A. (1983). Distributive justice, equity, and equality. Ann. Rev. Sociol. 9: 217-241.

Cook, K. S., and Yamagishi, T. (1983). Social determinants of equity judgments: The problem of multidimensional input. In Messick, D. M., and Cook, K. S. (eds.), Equity Theory: Psychological and Sociological Perspectives, Praeger, New York, pp. 95-126.

Dahrendorf, R. (1988). The Modern Social Conflict: An Essay on the Politics of Liberty, University of California Press, Berkeley.

Deutsch, M. (1985). The Social Psychology of Justice, Yale University Press, New Haven, CT. 
Deutsch, M., and Steil, J. (1988). Awakening the sense of injustice. Soc. Justice Res. 2: 3-23. Durkheim, E. (1893/1984). The Division of Labour in Society, MacMillan, London.

Engbersen, G. (1990). Publieke Bijstandsgeheimen: Het Ontstaan van een Onderklasse in Nederland [Public Welfare Secrets: The Emergence of an Underclass in the Netherlands], Stenfert Kroese, Leiden, The Netherlands.

Etzioni, A. (1988). I \& we: The case for the responsive community. Soc. Justice Res. 2: 81-94.

Gartrell, C. D. (1985). Relational and distributional models of collective justice sentiments. Soc. Forces 64: 64-83.

Gilligan, C. (1982). In a Different Voice: Psychological Theory and Women's Development, Harvard University Press, Cambridge, MA.

Griffith, W. I. (1990). The effect of inputs and performance outcomes on allocation decisions. Soc. Justice Res. 4: 35-47.

Hechter, M. (1987). Principles of Group Solidarity, University of California Press, Los Angeles.

Hermkens, P. (1983). Oordelen over de Rechtvaardigheid van Inkomens [Judgments on the Fairness of Incomes], Kobra, Amsterdam. The Netherlands.

Hermkens, P. L. J., and Boerman, F. A. (1989). Consensus with respect to the fairness of incomes: Differences between social groups. Soc. Justice Res. 3: $201-215$.

Hochschild, J.(1981). What's Fair? American Beliefs about Distributive Justice, Harvard University Press, Cambridge, MA.

Homans, G. C. (1961). Social Behavior: Its Elementary Forms, Harcourt Brace \& World, New York.

Homans, G. C. (1964). Bringing men back in. Am. Sociol. Rev. 29: 809-818.

Jasso, G. (1978). On the justice of earnings: a new specification of justice evaluation function. Am. J. Sociol. 83: 1398-1419.

Jasso, G. (1980). A new theory of distributive justice. Am. Sociol. Rev. 45: 3.32.

Jasso, G. (1989). The theory of the distributive-justice force in human affairs: Analyzing the three central questions. In Berger, J., Zelditch, M., Jr., and Anderson, B. (eds.), Sociological Theories in Progress: New Fomulations, Sage, Newbury Park, CA, pp. 354-387.

Jasso, G., and Rossi, P. (1977). Distributive justice and earned income. Am. Sociol. Rev. 42: 639-651.

Kluegel, J., and Smith, E. (1986). Beliefs About Inequality: American's Views of What is What Ought to $B e$, Aldine De Gruyter, New York.

Kohlberg, L. (1981). Essays on Moral Development, University of California Press, San Francisco.

Lemer, M. J. (1975). The justice motive in social behavior: An introduction. J. Soc. Issues 31: 1-19.

Lerner, M. J. (1977). The justice motive: Some hypotheses as to its origins and forms. $f$. Pers. 45: $1-52$.

Lemer, M. J. (1987). Integrating societal and psychological rules of entitlement: The basic task of each social actor and fundamental problem for the social sciences. Soc. Justice Res. 1: 107-125.

MacIntyre, A. (1988). Whose Justice, Which Rationality?, Duckworth, London.

Markovsky, B. (1985). Toward a multilevel distributive justice theory. Am. Sociol. Rev. 50: 822-839.

Marshall, T. H. (1965). Citizenship and social class. In Marshall, T. H., Class, Citizenship and Social Development, Doubleday \& Company, New York, pp. 71-134.

Martin, J., and Murray, A. (1983). Distributive injustice and unfair exchange. In Messick, D. M., and Cook, K. S. (eds.), Equity Theory: Psychological and Sociological Perspectives, Praeger, New York, pp. 169-205.

Mead, L. M. (1986). Beyond Entitlement: The Social Obligations of Citizenship, Free Press, New York.

Mishra, R. (1981). Society and Social Policy: Theories and Practice of Welfare, MacMillan, Houndmills, England.

Offe, C. (1991). A non-productivistic design for social policies. Paper presented at the Conference "Quality of Citizenship," March 20-22 1991, Utrecht, The Netherlands.

Rawls, J. (1973). A Theory of Justice, Oxford University Press, Oxford, England. 
Robinson, R., and Bell, W. (1978). Equality, success, and social justice in England and the United States. Am. Sociol. Rev. 43: 125-143.

Runciman, W. G. (1966). Relative Deprivation and Social Justice; A Study of Attitudes to Social Inequality in Twentieth Century England, University of California Press, Berkeley.

Rytina, S. (1986). Sociology and justice. In Cohen, R. L. (ed.), Justice: Views from the Social Sciences, Plenum Press, New York, pp. 117-151.

Schuyt, C. (1983). Tussen Macht en Moraal: Over de Plaats van het Recht in Verzorgingsstaat en Democratie [Between Power and Morality: On the Position of Law in Welfare State and Democracyl, Samsom, Alphen a/d Rijn, The Netherlands.

Shepelak, N. (1989). Ideological stratification: American beliefs about economic justice. Soc. Justice Res. 3: 217-231.

Shepelak, N., and Alwin, D. (1986). Beliefs about inequality and perceptions of distributive justice. Am. Sociol. Rev. 51: 30-46.

Steijn, B., and De Witte, M. (1991). Klasssepositie en opvattingen over sociale rechtvaardigheid [Class position and attitudes toward social justice]. In d'Anjou, L., and Bernts, T. (eds.), Presteren en Verdelen in Nederland: Over Individuele Belangen en Maatschappelijke Solidariteit [Achieving and Distributing in The Netherlands: On Individual Interests and Social Solidarity], Boom, Meppel/Amsterdam, The Netherlands, pp. 111-128.

Stolte, J. (1987). The formation of justice norms. Am. Sociol. Rev. 52: 774-784.

Tallman, J., and Ihinger-Tallman, M. (1979). Values, distributive justice and social change. Am. Sociol. Rev. 44: 216-235.

Titmuss, R. (1970). The Gift Relationship: From Human Blood to Social Policy, Allen and Unwin, London.

Törnblom, K. Y., and Foa, U. G. (1983). Choice of a distribution principle: Crosscultural evidence on the effects of resources. Acta Sociol. 26: 161-173.

Turner, B. (1990). Outline of a theory of citizenship. Sociology 24(2): 189-217.

Walster, E., Berscheid, E., and Walster, G. W. (1973). New directions in equity research. $J$. Pers. Soc. Psychol. 25: 151-176.

Walzer, M. (1983). Spheres of Justice: A Defence of Pluralism and Equality, Martin Robertson, Oxford, England.

Wilensky, H. L. (1975). The Welfare State and Equality: Structural and Ideological Roots of Public Expenditures, University of California Press, Berkeley.

Wilson, W. J. (1987). The Truly Disadvantaged: The Inner City, the Underclass, and Public Policy, University of Chicago Press, Chicago.

Wolfe, A. (1989). Market, state, and society as codes of moral obligation. Acta Sociol. 32: 221-236. 